\title{
Law and Development in Asia-Editor's Note to Special Issue
}

\author{
Jan Michiel OTTO*
}

Leiden University

This section of the present volume is devoted to "Law and Development in Asia." This phrase has been understood in at least two different ways. The first understanding refers simply to the role of law in the social and economic development of Asian countries. The second is about international legal assistance to Asian countries; this is indeed the subject matter of the three articles by Harding, Rahbari, and Kuong in this section. Harding and Kuong discuss the respective roles and experiences of Singapore and Japan in assisting with legal development in countries such as Myanmar, Vietnam, Cambodia, and Laos. Rahbari draws important lessons from a practitioner's perspective on the failures and successes of rule of law promotion in Afghanistan. In contrast, the articles by Zou and Zhang deal with the role of law in important aspects of social and economic development in China, respectively labour rights and the stock market. Both discuss the opportunities and constraints in how law deals with fundamental conflicts between goals of development and of governance.

Law and development in the sense of international programmes to assist "legal reform" and "the rule of law" in Asia have emerged on a large scale since the early 1990s. The Asian Development Bank and its general counsel, the late Barry Metzger, were among the most visible actors in this field. The financial crisis that hit Asia in 1997 was seen as evidence that, without proper legal systems, Asia's economic development was at risk.

By that time, rule of law and good governance had already become keywords in international development policy, notably since 1992, when the World Bank published its famous report on "Governance and Development." In 2017, the World Bank revisited this theme in its annual World Development Report entitled "Governance and the Law." The 25 years in between have witnessed not only expansion and change of international legal assistance in Asia, but also important developments within many of Asia's national legal systems. The extent to which the two are actually connected will never be known in full. Yet, this section offers at least some interesting glimpses and even a few clues about major trends.

The phrase "law and development" may sound very much like international jargon but, in most countries, it has older, domestic predecessors. For example, Hukum dan Pembangunan, Bahasa Indonesia for law and development, has been the name of the law journal that has been published since 1971 by the University of Indonesia's Faculty of Law in Jakarta. In 1969, even a department with the same name, Hukum dan Pembangunan, had been established in this faculty. Obviously, these were expressions of the prevailing notion that

Asian Journal of Law and Society Editor-in-Chief; Emeritus Professor of Law, Governance, and Development at Leiden University's Van Vollenhoven Institute for Law, Governance, and Society. 
"development" in the sense of sustainable social and economic progress was the country's main agenda and that law and lawyers too should play a role in this national enterprise.

Indeed, not all "law and development" is inspired by a single international agenda. About ten years before the 1992 World Bank Report appeared, senior Indonesian jurists had approached the Netherlands embassy in Jakarta expressing concern about decreasing legal expertise and suggesting assistance from Dutch legal experts who, supposedly, would understand the "Dutch-based" legal system of Indonesia and its needs. In response, the Dutch government decided to fund a large comprehensive programme of legal co-operation between both countries from 1985 onwards.

The three main components of that programme were legislative drafting, judicial capacitybuilding, as well as legal education and research. The fields covered were civil and commercial law, criminal law, administrative law, international law, and socio-legal studies. The programme that was supported by top legal scholars and practitioners in both countries reached many hundreds of Indonesian jurists and made significant contributions. Politically, it was quite sensitive, though, on both sides, and it came to an abrupt ending when, in March 1992, Indonesia's President Suharto, irritated by Dutch condemnation of gross human rights violations by the Indonesian army in East Timor, declared a complete stop of all Dutch development projects in Indonesia. Six years later, Suharto's regime fell and, in the subsequent reform period, the fruits of the comprehensive co-operation programme would become all too visible.

Meanwhile, this co-operation had been a learning experience not only for the Indonesian, but also for the Dutch participants. Unexpectedly, this proved to be a crucial asset when the need arose for legal-reform assistance to the former Soviet Union and Eastern Europe. Dutch experts would play an important advisory role as post-Communist Russia and its satellite states reformed their civil codes and civil-procedure codes in the 1990s. By the way, this reform bears significant similarities with the Japanese experience in Vietnam.

Whatever the merits may be of "law and development" as international legal assistance, it is always secondary to the domestic development of national law in its historical, political, social, and economic context. Therefore, broad knowledge and deep understanding of such law and its context remain a vital requirement to understanding "law and development," in both of its meanings, as this section testifies. 